\title{
Use of Mining Waste to Produce Ultra-High-Performance Fibre-Reinforced Concrete
}

\author{
Jesús Suárez González ${ }^{1}$ ** , Iñigo Lopez Boadella ${ }^{1}$ [ , Fernando López Gayarre ${ }^{1}$, \\ Carlos López-Colina Pérez ${ }^{1}\left[\right.$, Miguel Serrano López ${ }^{1}\left[\right.$ and Flavio Stochino ${ }^{2}$ () \\ 1 Poliytechnic School of Engineering, Campus de Viesques, University of Oviedo, 33203 Gijón, Spain; \\ inigo2208@hotmail.com (I.L.B.); gayarre@uniovi.es (F.L.G.); lopezpcarlos@uniovi.es (C.L.-C.P.); \\ serrano@uniovi.es (M.S.L.) \\ 2 Department of Civil, Environmental and Architectural Engineering, University of Cagliari, \\ 09100 Cagliari, Italy; fstochino@unica.it \\ * Correspondence: suarezg@uniovi.es
}

Received: 1 May 2020; Accepted: 26 May 2020; Published: 28 May 2020

\begin{abstract}
This research work analyses the influence of the use of by-products from a fluorite mine to replace the fine fraction of natural aggregates, on the properties of Ultra-High-Performance Fibre-Reinforced Concrete (UHPFRC). Replacing natural aggregates for different kinds of wastes is becoming common in concrete manufacturing and there are a number of studies into the use of waste from the construction sector in UHPFRC. However, there is very little work concerning the use of waste from the mining industry. Furthermore, most of the existing studies focus on granite wastes. So, using mining sand waste is an innovative alternative to replace natural aggregates in the manufacture of UHPFRC. The substitutions in this study are of $50 \%, 70 \%$ and $100 \%$ by volume of $0-0.5 \mathrm{~mm}$ natural silica sand. The results obtained show that the variations in the properties of consistency, compressive strength, modulus of elasticity and tensile strength, among others, are acceptable for substitutions of up to $70 \%$. Therefore, fluorite mining sand waste is proved to be a viable alternative in the manufacturing of UHPFRC.
\end{abstract}

Keywords: mining waste; ultra-high performance fibres reinforced concrete; compressive strength; flexural strength

\section{Introduction}

In 1973, the overexploitation of natural resources and environmental degradation due to the waste generated in industry, mining, etc. motivated the European Union to launch its Environment Action Program. This program is currently in its seventh edition. The latest resolutions, passed in 2013, prioritize increasingly efficient use of resources to make the European Union an intelligent, sustainable and inclusive economy. Construction is one of the most affected sectors, so the use of waste as a resource is currently a priority in the research lines of many institutions in this sector, particularly in relation to the manufacturing of concrete.

Ultra High Performance Concrete (UHPC) emerged in the early 1990s, when P. Richard [1] developed a new type of concrete that offered a compressive strength of over $200 \mathrm{MPa}$, a bending strength above $40 \mathrm{MPa}$, and some ductility. In 2002 the first recommendations for the structural use of these concretes ware published in France [2]. In 2005, noteworthy research work was carried out in Germany, building the groundwork for the basic knowledge needed to develop a reliable, economically feasible UHPC [3]. UHPC has been developed further in recent decades and is valued for its high mechanical strength and very low porosity. 
The incorporation of short steel fibres in these concretes improves the performance of the structures against flexotraction, controls and reduces cracking. These concretes are called Ultra-High-Performance Fibre-Reinforced Concrete (UHPFRC). Abbas et al. [4] reported that the incorporation of short steel fibres, increases the load against the first crack and the maximum load, as well as making it possible to double or triple the tensile strength of UHPC. Although the Association Française de Génie Civil considers UHPC as that having a compressive strength higher than $150 \mathrm{MPa}$ [2], it is very common to classify concrete with a compressive strength of over 100MPa as UHPC. In this regard, F. Canovas qualifies concrete as having very-high strength when it has a compressive strength higher than $90 \mathrm{MPa}$ and as having ultra-high strength when its compressive strength is higher than $125 \mathrm{MPa}$ at 28 days [5].

Ecologically, however, UHPC has problems in terms of sustainability, since it uses very fine fractions of natural aggregates, especially silica sands, which require significant energy for grinding. Therefore, there is a need to find and supply alternative materials to avoid or reduce their use. The use of recycled materials or construction by-products as a total or partial substitution of natural aggregates in the search for a more sustainable UHPC is currently being researched. Ambily el al. [6] study the use of copper slags as an alternative to the finest aggregate in UHPC. With 100\% substitution of the fine aggregate, variations in flexural strength are negligible, and despite the slight reported loss of compressive strength, the final values are above $150 \mathrm{MPa}$. Zhu et al. [7] and Zhao et al. [8] use iron tailings as an alternative to natural aggregate. They observed that up to $40 \%$ substitution, the mechanical properties of the UHPC were coMParable to those of the control concrete. In addition, Zhao et al. [8] showed that if the maximum size of the iron tailings was under $1.20 \mathrm{~mm}$, a substitution of $60 \%$ is viable.

Glass waste is another type of material that can be used to substitute aggregates. Yang et al. [9] and Soliman and Tagnit-Hamou [10] have shown that using recycled glass to replace the natural sand gives promising mechanical properties in UHPC. For a ratio of $50 \%$ substitution, the slump and the compressive strength are coMParable to the control UHPC mix [10]. Following this same line of research, Zegardlo et al. [11] have shown that ceramic waste is another alternative to natural aggregate in the manufacture of UHPC. The results show that the compressive strength improves by $24 \%$ and the tensile strength rises to $34 \%$.

The abovementioned studies focus on the use of waste from the construction sector. However, there are only a few studies that focus on incorporating waste from the extractive industry in the manufacture of concrete, specifically HPC and UHPC. The studies in which granite cutting waste is used as a substitution for fine aggregate in UHPC is relevant in this area. Sarbjeet et al. [12] showed that a substitution of $40 \%$ of the aggregate had a positive iMPact on the flexural strength while for a ratio of $70 \%$ the results were coMParable to those of the control concrete. López Boadella et al. [13] observed an increase in flexural strength and tensile strength by substituting $35 \%$ of micronized quartz with fine granite cutting waste. Similar results were provided by Kala [14] who found that the incorporation of granite fines as a partial replacement for sand has a positive effect on the properties of HPC in relation to compressive strength, flexural strength and tensile strength.

Mining, which is one of the greatest waste-generating activities $[15,16]$ is the focus of this research. This a study of the feasibility of the utilization of by-products from a fluorite $\left(\mathrm{CaF}_{2}\right)$ mine as a replacement for natural aggregates in the manufacture of UHPFRC. This silica sand comes from the mine's washing installations. Once treated and washed, it could be used in the manufacture of UHPC. However, it cannot be used in conventional concrete due to the high percentage of fines. To the best of the authors' knowledge, there are no previous studies on the use of this type residue. The studies than come close are those already mentioned, which refer to granite fines. So, the main objective of this research is the innovative use of this by-product as a substitute for natural aggregates in the manufacture of UHPFRC. 


\section{Experimental Study}

\subsection{Description of the Materials Used}

Type I 42.5 R/SR Ordinary Portland Cement (OPC, Lafarge-Holcim, Madrid, Spain) was used. As additions for the mix, two materials were used: densified silica fume (Elkem Microsilica®940, Elkem, Barcelona, Spain) with a $0.15 \mu \mathrm{m}$ average particle size and micronized quartz with a maximum particle size of $40 \mu \mathrm{m}$. The steel fibres (Arcelor Mittal, Asturias, Spain) used in the research had a diameter of $0.2 \mathrm{~mm}$ and a length of $13 \mathrm{~mm}$. As natural aggregates, two types of siliceous sands (Sílices La Cuesta, Asturias, Spain) with granulometric fractions $0-0.5 \mathrm{~mm}$ and $0.5-1.6 \mathrm{~mm}$ were used. In order to achieve optimum workability, a polyxycarboxylate superplasticizer was used. (Sika ViscoCrete-225 Powder, Sika, Madrid, Spain). Finally, as a substitute for the finest fraction of the sand, waste mining sand (WMS) (Minersa, Ribadesella, Spain), which is generated in the process of obtaining fluoride or fluorite spar in fluorite mines, was used (Figure 1a,b).

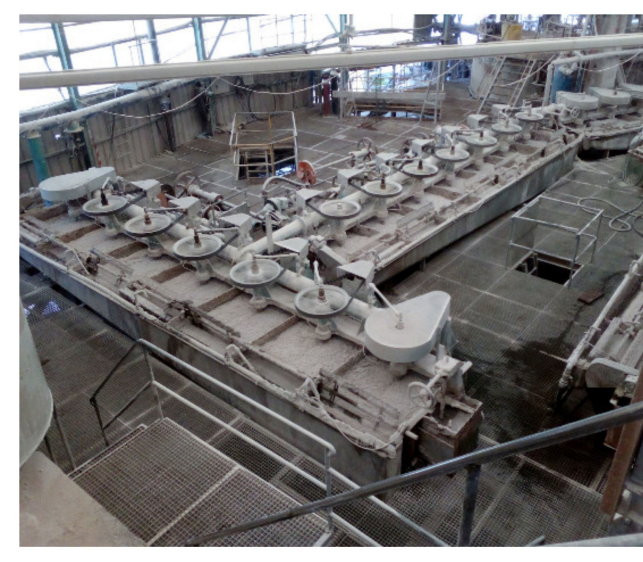

(a) Fluorite mine washing installations

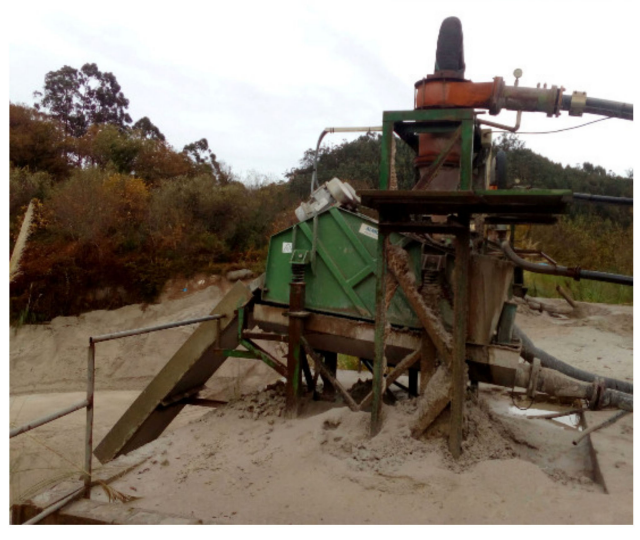

(b) Waste draining system

Figure 1. Obtaining residual mine sand.

Table 1 shows a summary of the main properties of all the materials used. The greatest amount of fine particles present in the WMS is in the sand equivalent test.

Table 1. Properties of the materials.

\begin{tabular}{cccccc}
\hline Properties & $\begin{array}{c}\text { Aggregate } \\
\mathbf{0 - 0 . 5} \mathbf{~ m m}\end{array}$ & $\begin{array}{c}\text { Aggregate } \\
\mathbf{0 . 5 - 1 . 6 ~} \mathbf{~ m m}\end{array}$ & $\begin{array}{c}\text { Micronized } \\
\text { Quartz }\end{array}$ & Silica Fume & $\begin{array}{c}\text { Waste Mining } \\
\text { Sand }\end{array}$ \\
\hline Bulk density $\left(\mathrm{kg} / \mathrm{m}^{3}\right)$ & 2616 & 2616 & 2609 & 2300 & 2717 \\
Sand equivalent & 97 & 97 & - & - & - \\
Absorption $24 \mathrm{~h}$ & $0.28 \%$ & $0.53 \%$ & - & $<3.00 \%$ & $0 \%$ \\
Humidity $(\%)$ & $0 \%$ & $0 \%$ & $<0.2 \%$ & & \\
\hline
\end{tabular}

The chemical composition of the WMS is determined by X-ray fluorescence. The results obtained are shown in Table 2, where L.O.I stands for Loss on Ignition. The second most significant component is $\mathrm{CaO}$, at $10 \%$. The percentages of $\mathrm{Al}_{2} \mathrm{O}_{3}$ and $\mathrm{Fe}_{2} \mathrm{O}_{3}$ are approximately $1.5 \%$, higher than those of the $0-0.5 \mathrm{~mm}$ silica sand.

Table 2. Chemical analysis (\%) of the waste mining sand and the natural sand it replaces.

\begin{tabular}{cccccccccccc}
\hline Material & $\mathrm{SiO}_{2}$ & $\mathrm{CaO}$ & $\mathrm{Fe}_{2} \mathbf{O}_{3}$ & $\mathrm{Al}_{2} \mathbf{O}_{3}$ & $\mathbf{M g O}$ & $\mathbf{K}_{2} \mathrm{O}$ & $\mathbf{N a}_{2} \mathrm{O}$ & $\mathrm{TiO}_{2}$ & $\mathbf{P}_{2} \mathbf{O}_{5}$ & $\mathbf{M n O}$ & L.O.I \\
\hline Waste mining sand & 71.65 & 10.8 & 1.66 & 1.5 & 1.21 & 0.57 & 0.13 & 0.11 & 0.03 & 0.01 & 8.82 \\
Aggregate 0-0.5 mm & 99.34 & $<0.1$ & $<0.13$ & 0.30 & $<0.1$ & $<0.1$ & $<0.03$ & $<0.1$ & $<0.1$ & - & 0.23 \\
\hline
\end{tabular}


Figure 2 shows the particles size distribution of the materials used. A difference between the granulometry of the $0-0.3 \mathrm{~mm}$ WMS, and the fraction of $0-0.5 \mathrm{~mm}$ silica sand which it substitutes, can be seen. The granulometric distribution of silica fume is a consequence of its densification. Its maximum particle size is $0.15 \mu \mathrm{m}$.

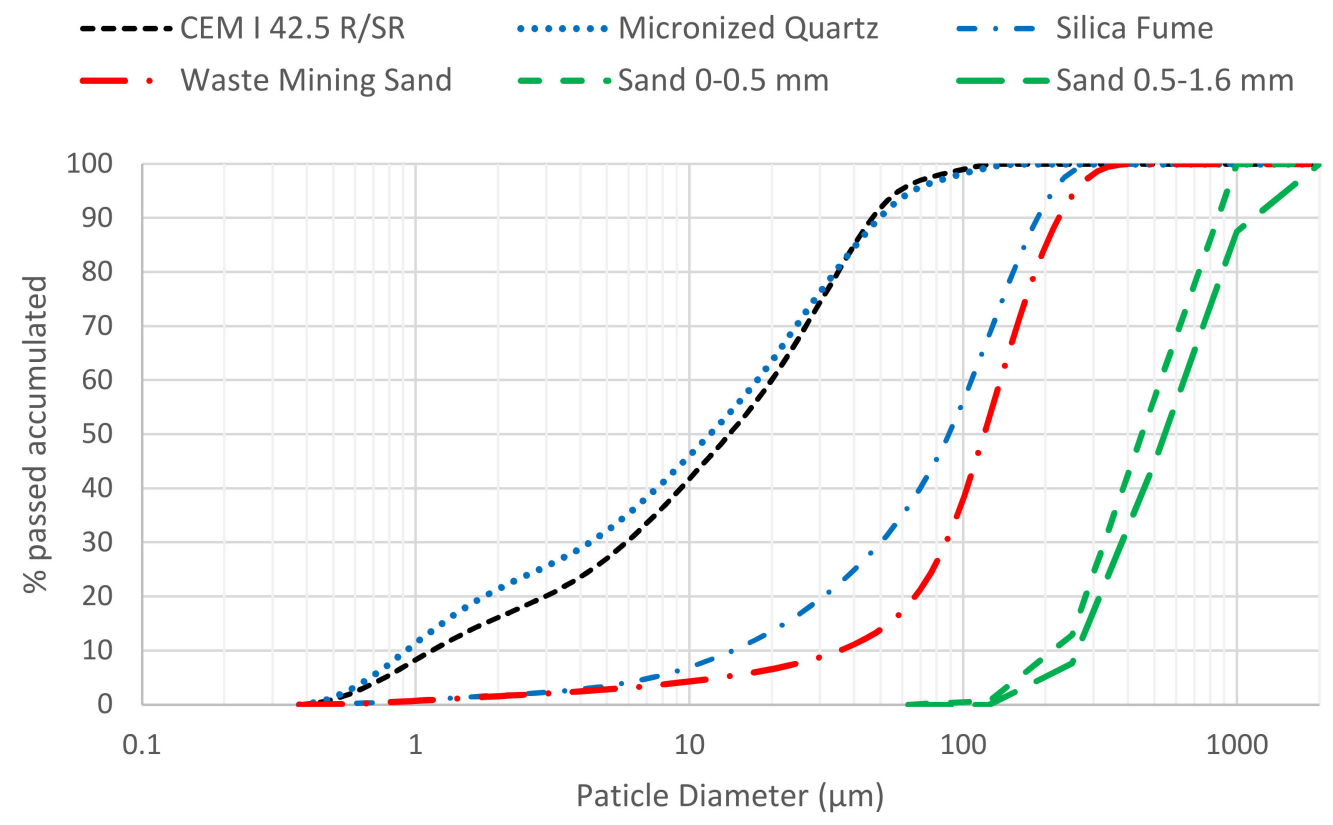

Figure 2. Grading curves of the materials.

\subsection{Mix Design}

To develop this research, the starting point was a self-coMPacting reference concrete with a compressive strength of more than $117 \mathrm{MPa}$. From this control mix, the experimental program was developed with replacements of $50 \%, 70 \%$ and $100 \%$ of $0-0.5 \mathrm{~mm}$ of silica sand for the same volume of WMS. Substitutions below $50 \%$ were not done as the results obtained for these percentages were satisfactory.

Table 3 shows the proportions of each of the UHPFRC mixes manufactured.

Table 3. Dosages of Ultra High Performance Fibre Reinforced Concrete (UHPFRC) $\left(\mathrm{kg} / \mathrm{m}^{3}\right)$.

\begin{tabular}{ccccc}
\hline Material & Control & $\mathbf{5 0} \%$ WMS & $\mathbf{7 0} \% \mathbf{W M S}$ & $\mathbf{1 0 0} \%$ WMS \\
\hline Cement & 800 & 800 & 800 & 800 \\
Sand 0-0.5 mm & 302 & 151 & 91 & - \\
Waste mining sand & - & 161 & 225 & 321 \\
Sand 0.5-1.6 mm & 565 & 565 & 565 & 565 \\
Micronized quartz & 225 & 225 & 225 & 225 \\
Silica fume & 175 & 175 & 175 & 175 \\
Water & 175 & 175 & 175 & 175 \\
Superplasticizer & 10 & 10 & 10 & 10 \\
Steel fibres & 160 & 160 & 160 & 160 \\
\hline
\end{tabular}

Figure 3 shows the grading curves of the total aggregate of the different UHPFRC mixes. As the percentage of substitution of the finest fraction of the sand for WMS increases, the percentage of particles with a size between $50 \mu \mathrm{m}$ and $300 \mu \mathrm{m}$ increases. This increase generates grading curves with a more continuous progression, given that the depression that occurs in the range between $50 \mu \mathrm{m}$ and $1 \mathrm{~mm}$ for the control concrete is corrected. Because of this, the curves resulting from the use of mine 
sand are more similar to the ideal packing curve proposed by authors such as Andreasen or Funk and Dinger [17].

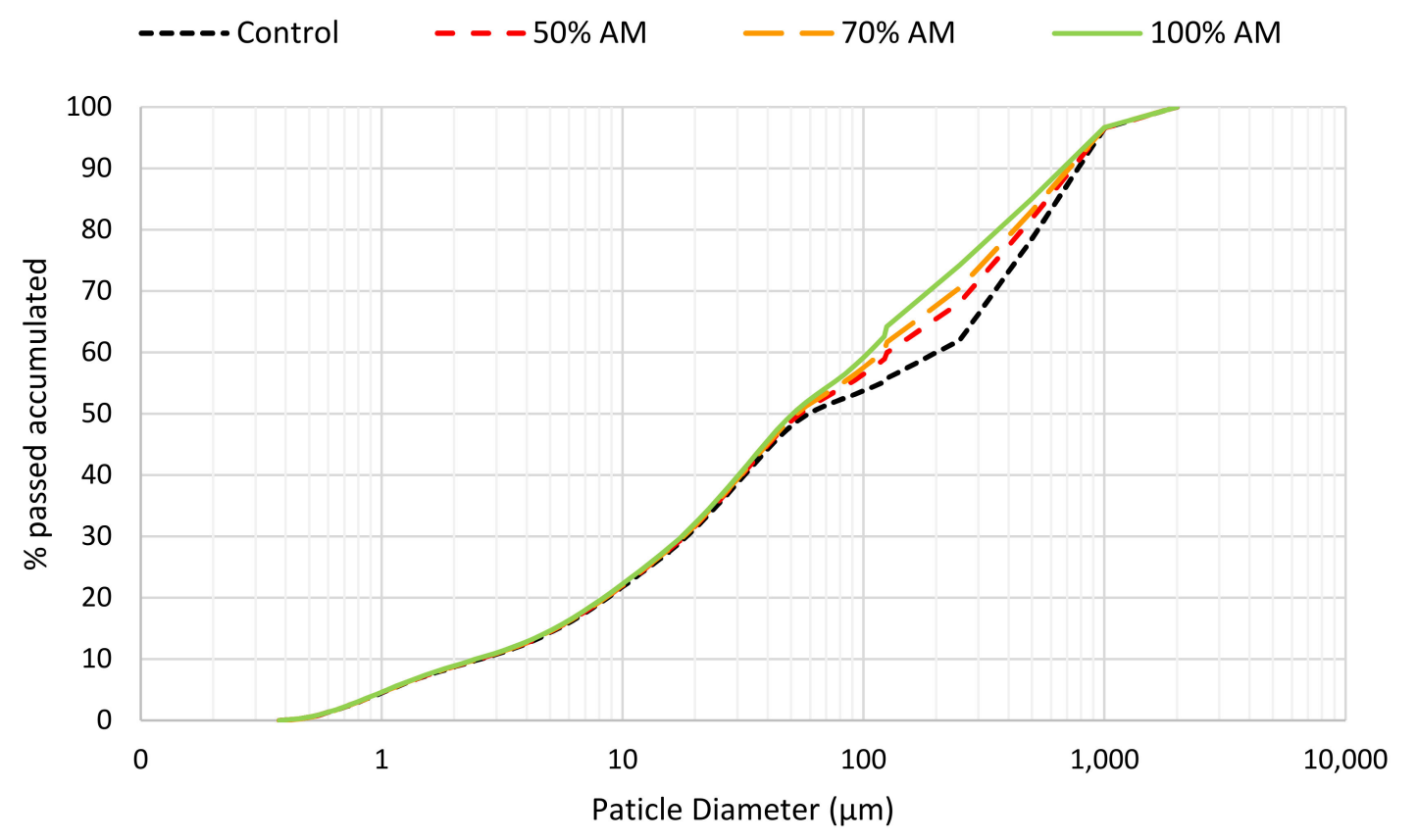

Figure 3. Grading curves of UHPFRC.

\subsection{Development of the Experimental Program}

The mix procedure is as follows: first the two parts of silica sand and/or the WMS are introduced in the mixer, followed by the micronized quartz, the silica fume and finally the cement. They are mixed for $30 \mathrm{~s}$ and then the whole amount of water is poured in. Mixing continues for 2 min more, after which the superplasticizer additive and the steel fibres are added. The whole mixing process ends after $25 \mathrm{~min}$.

Nine specimens were manufactured for each mix, according to the specifications of standard UNE-EN 12390-1 [18]: three $\varnothing 15 \times 30 \mathrm{~cm}$ cylindrical specimens, three $10 \times 10 \times 10 \mathrm{~cm}$ cubic specimens and three $10 \times 10 \times 40 \mathrm{~cm}$ prismatic specimens. The specimens were cured in a humid chamber at a temperature of $20 \pm 2{ }^{\circ} \mathrm{C}$ and a relative humidity of $95 \%$ for 28 days following the specifications of the UNE-EN 12390-2 standard [19].

The following properties were measured: the consistency of fresh UHPFRC according to the NF P 18-470 standard [20], the density of hardened UHPFRC following the UNE-EN 12390-7 standard [21], the modulus of elasticity (UNE- EN 12390-13) [22], compressive strength (UNE-EN 12390-3) [23], flexural strength (NF P 18-470) [20] and tensile strength (NF P standard 18-470) [20].

Table 4 shows a summary of the results obtained in this study. All values, except slump, correspond to the average value of the three results obtained in each of the tests performed.

Table 4. Results of the experimental program.

\begin{tabular}{ccccc}
\hline Properties & Control & \multicolumn{3}{c}{ Difference (\%) } \\
\cline { 3 - 4 } & & $\mathbf{5 0 \%}$ WMS & $\mathbf{7 0 \%}$ WMS & $\mathbf{1 0 0 \%}$ WMS \\
\hline Slump $(\mathrm{cm})$ & 25.0 & $16.0 \%$ & $4.0 \%$ & $20.0 \%$ \\
Density $\left(\mathrm{kg} / \mathrm{m}^{3}\right)$ & 2410.0 & $-1.2 \%$ & $-1.7 \%$ & $-2.1 \%$ \\
Compressive strength $(\mathrm{MPa})$ & 117.2 & $9.9 \%$ & $11.8 \%$ & $11.2 \%$ \\
Modulus of elasticity $(\mathrm{GPa})$ & 45.2 & $-3.5 \%$ & $-5.8 \%$ & $-6.4 \%$ \\
Flexural strength $(\mathrm{MPa})$ & 23.0 & $-7.0 \%$ & $-3.5 \%$ & $-17.4 \%$ \\
Tensile strength $(\mathrm{MPa})$ & 8.7 & $9.2 \%$ & $-1.1 \%$ & $-20.7 \%$ \\
\hline
\end{tabular}




\section{Analysis of Results}

\subsection{Consistency of Fresh UHPFRC}

Figure 4 shows the results obtained. In the three mixes there is an increase in the consistency of fresh UHPFRC, of between $4 \%$ and $25 \%$. This improvement may be related with the variation in the granulometry of WMS $(0-0.3 \mathrm{~mm})$, in relation to the fraction of substituted silica sand $(0-0.5 \mathrm{~mm})$. It may also be related to the variation experienced by the grading curve of the mixtures in the range 0.1-0.5 $\mathrm{mm}$ when introducing the mine sand, since a more continuous distribution of the particle size is observed. This will improve packaging and reduce water requirements [24].

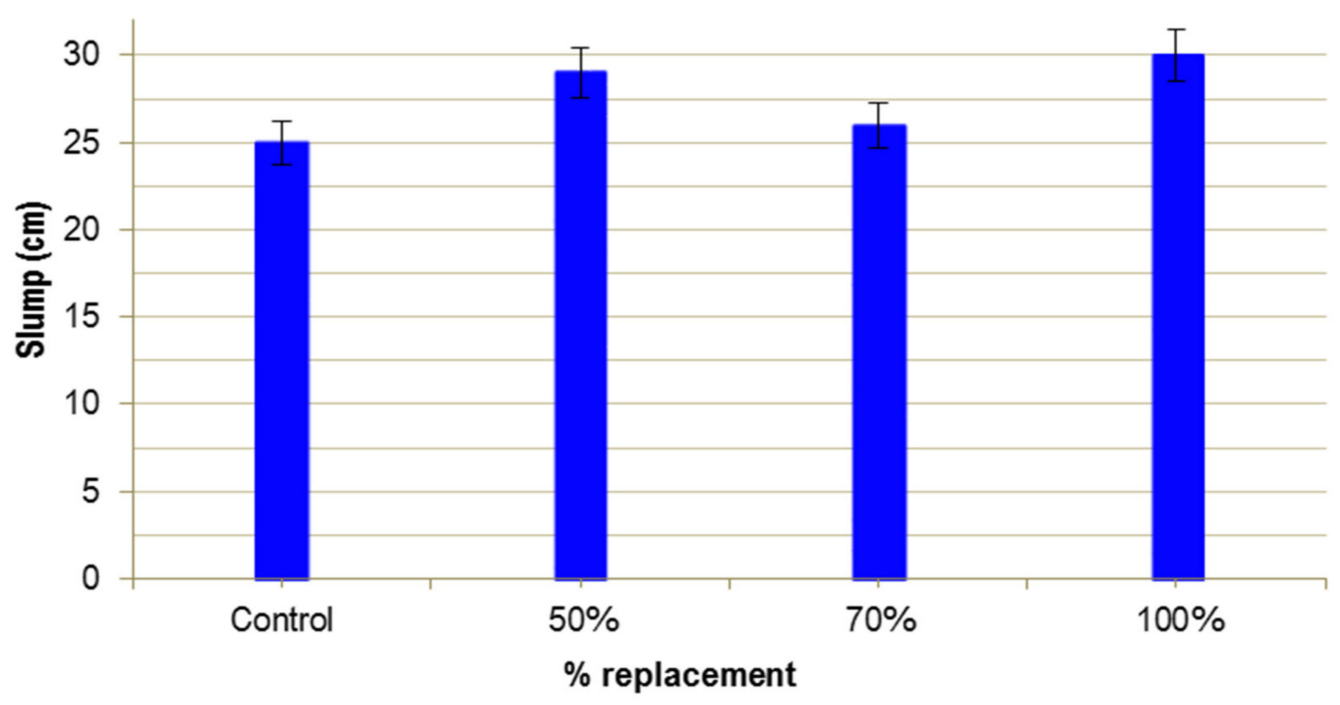

Figure 4. Slump of UHPFRC.

Differences between these results and those obtained by other authors can be explained by the characteristics of the type of waste used. Soliman and Tagnit-Hamou [10] observed an improvement in slump flow by incorporating glass powder, with slightly larger average particle diameter, as partial or total substitution of quartz sand. Similar results were obtained by Pyo et al. [25] when substituting the finest silica sand with waste generated in a tungsten mine. For substitutions of 50\% and $100 \%$ there is an improvement in the flow of fresh concrete greater than 30\%. However, Kou [26] and Zhao et al. [8] observe a decrease in flowability in their tests when using other types of waste. Kou [26] shows a loss in the flowability of UHPFRC when discarded fly ash is incorporated as a substitution for silica sand. Kou attributes this loss of flowability to a greater amount of fines present in fly ash. Zhao et al. [8] observed that substituting $100 \%$ of the natural aggregate with iron ore tailings produced a significant decrease in the flowability of the UHPC due to the more angular and irregular shape of the tailings.

\subsection{Density of the Hardened UHPFRC}

Figure 5 shows the values obtained for the different substitution percentages. As the percentage of WMS increases, there is a minimal density reduction, around $2 \%$ for a $100 \%$ substitution. These variations in density are so slight as to be within the range of variability of the results obtained, as shown in the error bars in Figure 5. Therefore, the use of WMS has a negligible influence on the density of hardened UHPFRC. 


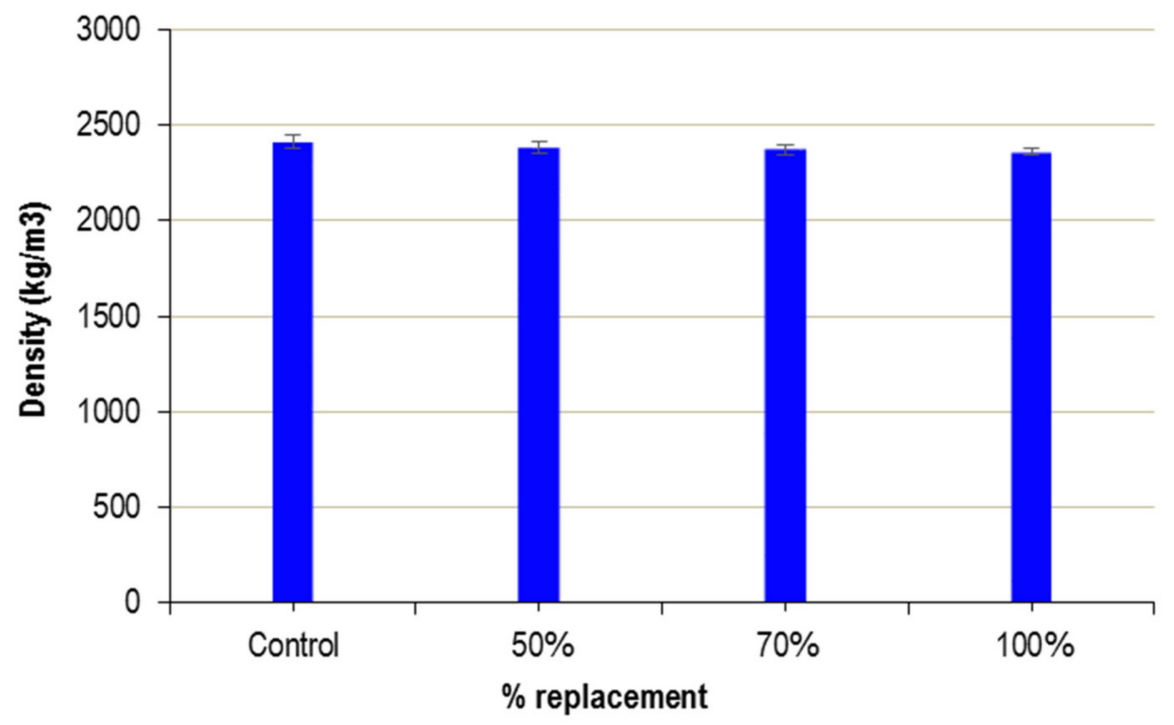

Figure 5. Density of UHPFRC.

\subsection{Compressive Strength}

There is an increase in strength for all degrees of substitution, as shown in Figure 6. This may be due to the difference between the maximum aggregate size of silica sand $(0.5 \mathrm{~mm})$ and that of sand from the fluorite mine $(0.3 \mathrm{~mm})$ since, especially in cement-rich concrete. The smaller the maximum particle size, the greater the compressive strength of the concrete [27-29].

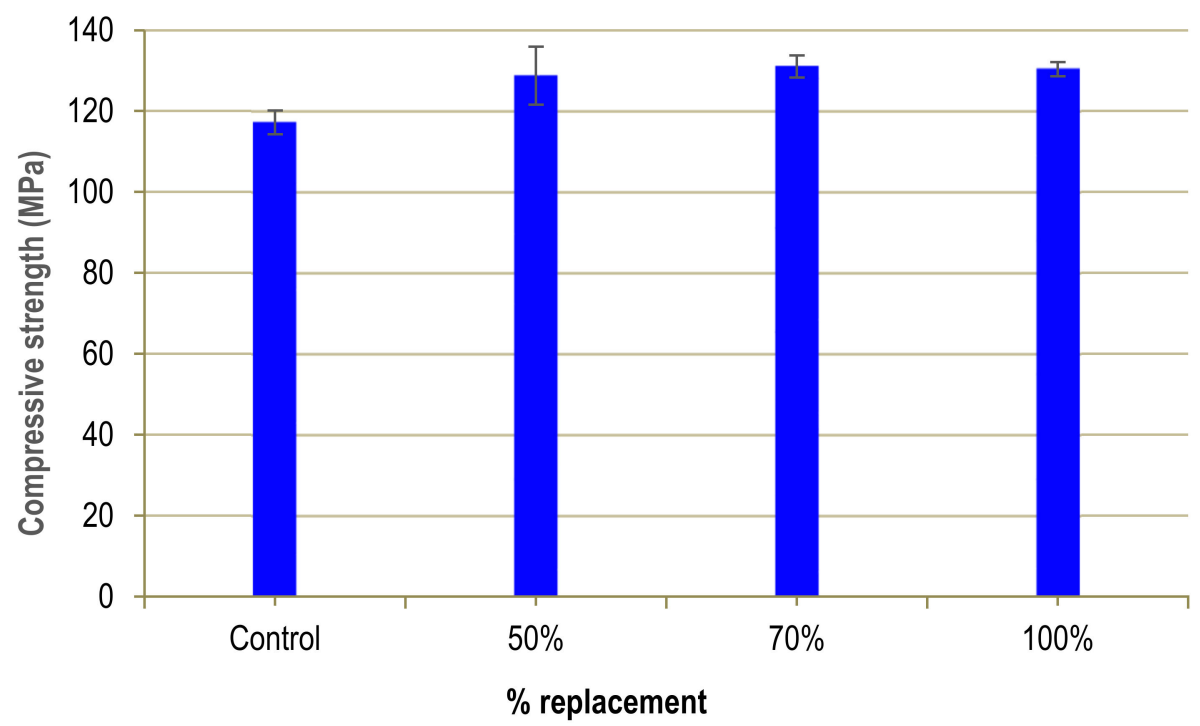

Figure 6. Compressive strength of UHPFRC.

These increases in the compressive strength of concrete are in line with the results obtained by Zegardlo, [11] who obtained an increase in strength of $24.7 \%$ when using ceramic waste as an alternative to natural aggregate. He attributes this improvement to the formation of mechanical hooks in the interfacial transition zone (ITZ), which generate better adhesion with the cement paste and greater strength. Similar results were obtained by Zhu [7] who observed an increase in compressive strength by incorporating $0-1.20 \mathrm{~mm}$ iron ore tailings to substitute $0-4.75 \mathrm{~mm}$ siliceous sands, independently of the percentage of substitution. However, other authors obtain less favourable results, depending on 
the waste used: Soliman and Tagnit-Hamou report a loss of compressive strength of $15 \%$ for a $100 \%$ substitution in their study using glass waste as an alternative to quartz sand [10].

\section{Elasticity Modulus}

Figure 7 displays the effect of WMS on the elasticity modulus of the UHPFRC. A slight and progressive decrease in the modulus of elasticity values can be seen as the substitution percentage increases. However, this difference is small, not exceeding $6 \%$.

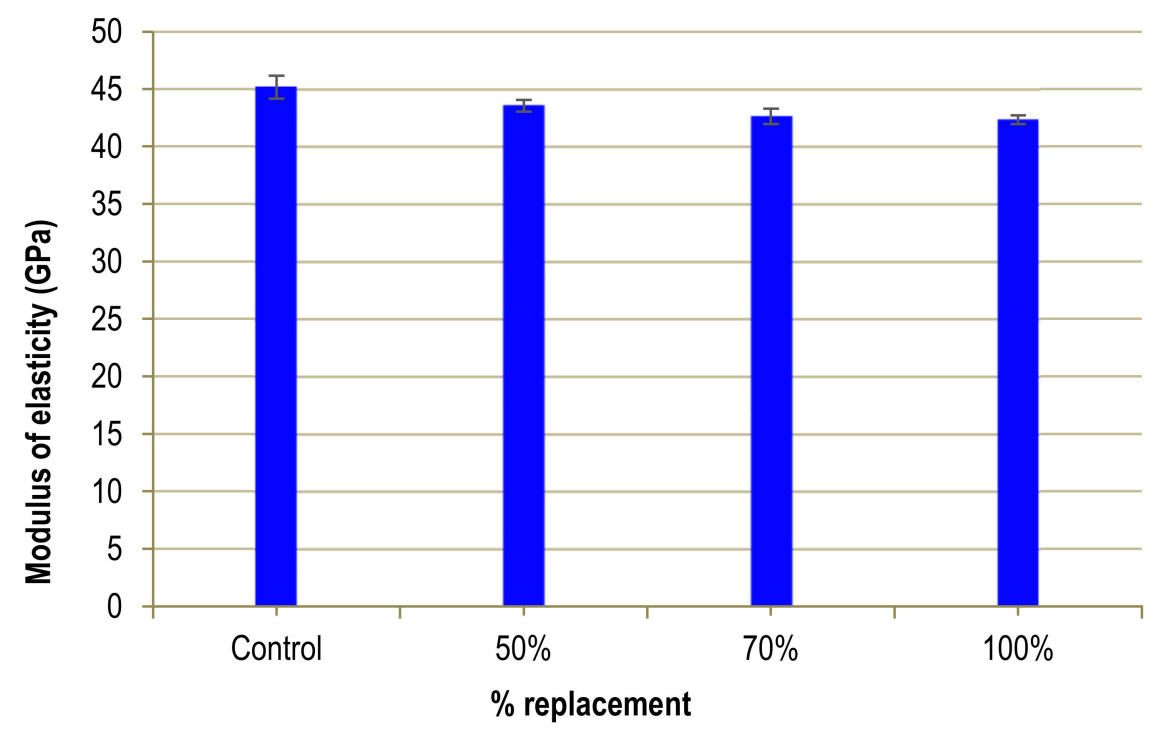

Figure 7. Modulus of Elasticity of UHPFRC.

This low influence on the modulus of elasticity is also reflected in the results obtained by Alsalman [30], when substituting sand with fly ash. According to the author, this may be due to an excess of fly ash, which makes it impossible for $100 \%$ of these particles to be hydrated. This counteracts the positive effect of hydrated ash.

Gonzalez-Corominas and Etxeberria [31] also observed a decrease in the modulus of elasticity (around 5\%), although their study refers to low substitution percentages (less than $30 \%$ ) and uses ceramic waste to manufacture high performance concrete (HPC). They relate this reduction to the lower density of the concrete derived from using ceramic waste.

\subsection{Flexural Strength}

The results regarding flexural strength, shown in Figure 8, are stable up to $70 \%$ substitution, when they rise slightly. In general, the trend is declining and drops to $17 \%$ for a substitution of $100 \%$. For lower percentages the variation is smaller, less than $7 \%$. The variability of the results may be due to the randomness of the distribution of steel fibres.

The explanation may be in the inferior quality of mine sand, since it has $10 \% \mathrm{CaO}$, as opposed to the natural sand it substitutes, which is almost $100 \% \mathrm{SiO}_{2}$. This could counteract the advantageous results produced by the improvement in the grading curve for high percentage substitutions, because of the lower mechanical resistance of the mine sand. In general, the result is similar to that obtained by Zhao et al. [8] and Zhu et al. [7] who use iron ore tailings as an alternative to natural aggregate. The concrete loses $18 \%$ of its flexural strength when $100 \%$ of the natural aggregate is substituted, while for the rest of the percentages the variations are very small. These results are also similar to those obtained by Taha [32], who uses glass waste as an alternative to natural aggregate in UHPC without fibres, although the results of flexural strength are not coMParable due to the lack of fibres. However, the results obtained by this author show a decrease in flexural strength of $21 \%$, when $100 \%$ of the fine 
aggregate is substituted. Taha considers that this loss of strength may be a consequence of small cracks present in the particles of the glass waste, or the presence of organic materials, which can degrade over time, creating hollows in the microstructure of the concrete.

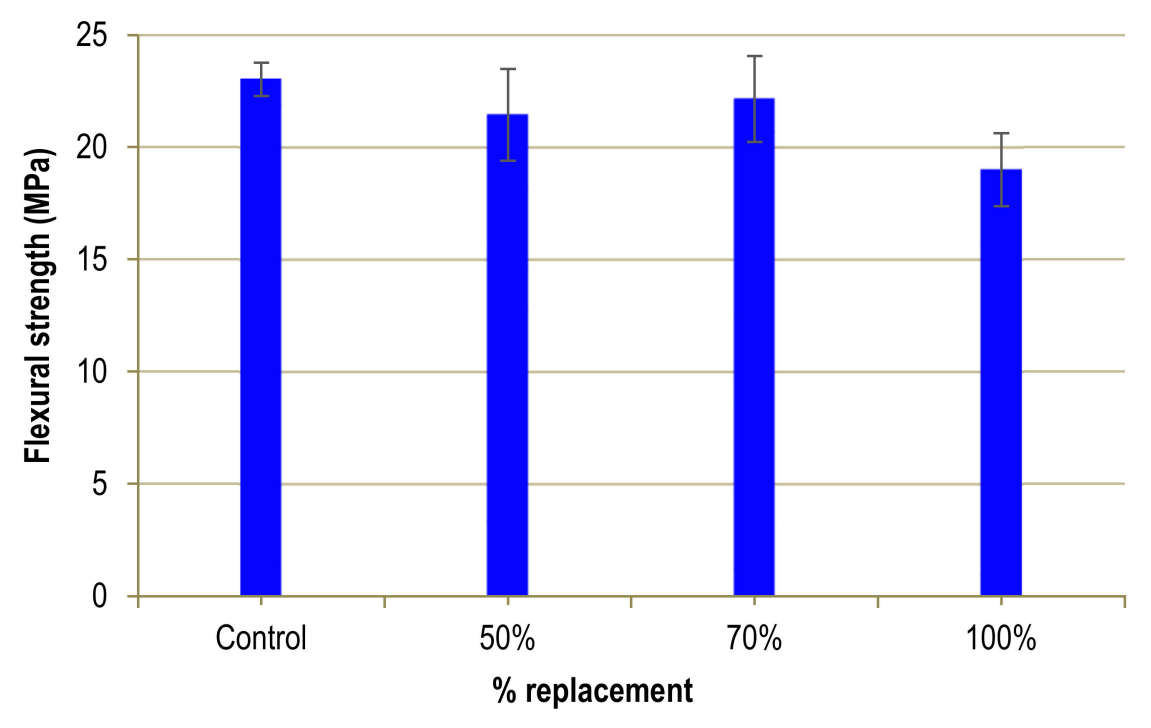

Figure 8. Flexural strength of UHPFRC.

\subsection{Tensile Strength}

In order to determinate the tensile strength of UHPFRC the stress-strain curves from the flexural tests have been taken as the starting point as seen in Figure 9.

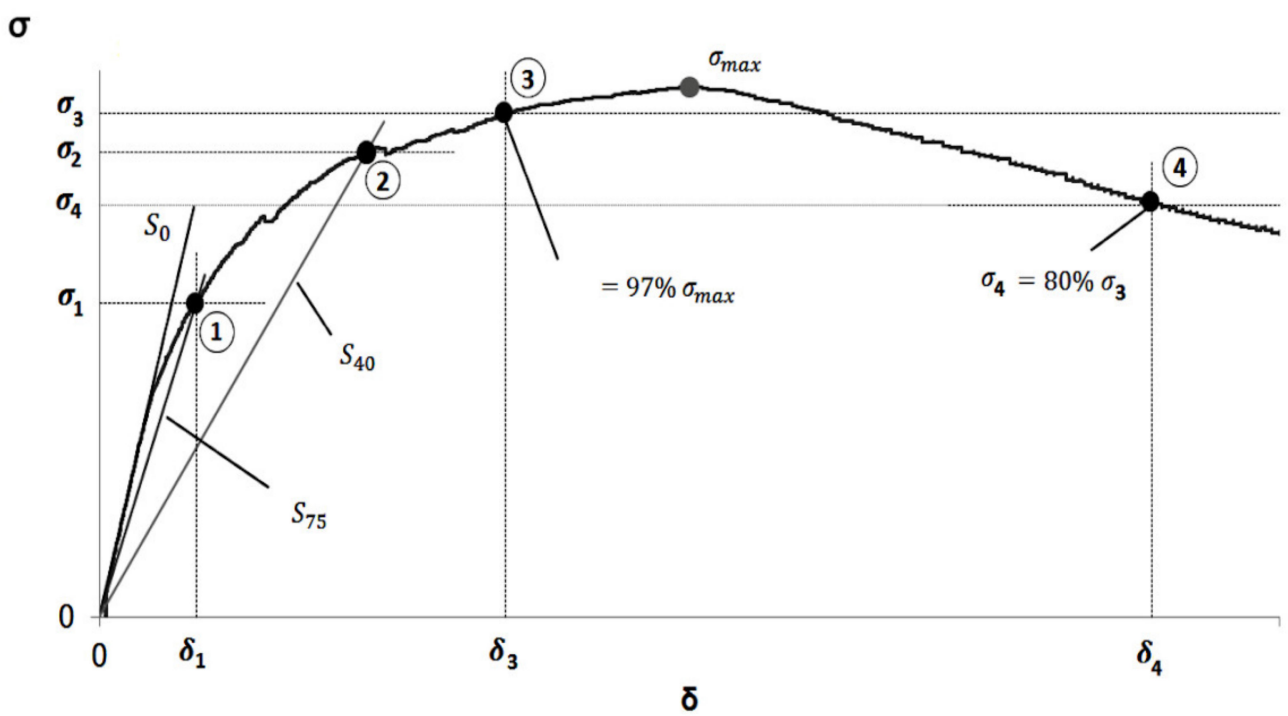

Figure 9. Stress-strain curves and key points.

From the curve obtained, the key points [33] necessary to determine the tensile behaviour were determined, using the following points:

Point 1 is the intersection of the curve test with a line of a slope equal to 0.75 of the slope of the elastic zone of the curve.

Point 2 is the intersection of the curve test with a line of a slope equal to 0.40 of the slope of the elastic zone of the curve. 
Point 3 is the point of the ascending zone of the curve, with $97 \%$ of the highest stress.

Based on these points, the tensile strength of the UHPFRC can be obtained by the following equations [33]:

$$
\begin{gathered}
E=2.40 \mathrm{hm} \\
f_{t}=\frac{\sigma_{75}}{1,63}\left(\frac{\sigma_{75}}{\sigma_{40}}\right)^{0.19} \\
\varepsilon_{t, u}=\frac{f_{t}}{E}\left(7.65 \frac{\delta_{l o c}}{\delta_{75}}-10.53\right) \\
\varepsilon_{t, e l}=f_{t} / E \\
\alpha=\varepsilon_{t, u} / \varepsilon_{t, e l} \\
f_{t, u}=\alpha^{-0.18}\left(2.46 \frac{\sigma_{l o c}}{\sigma_{75}}-1.76\right) f_{t}
\end{gathered}
$$

Where the pair of values $\left(\sigma_{75}, \delta_{75}\right),\left(\sigma_{40}, \delta_{40}\right)$, and $\left(\sigma_{l o c}, \delta_{l o c}\right)$ correspond respectively with points 1 , 2 and 3 in the curve of Figure 9. Equation (1) represents the value of elasticity modulus $(E)$ in function of the slope $(m)$ of the elastic region of the stress-strain curve and the thickness $(h)$ of the specimen in $\mathrm{mm}$. Equation (2) refers to the crack resistance $\left(f_{t}\right)$ of the matrix reinforced with fibres, Equation (3) calculates the peak deformation $\left(\varepsilon_{t, u}\right)$, Equations (4) and (5) refers to the standardised parameters $\varepsilon_{t, e l}$ and $\alpha$, and Equation (6) represents the value of the ultimate tensile strength $\left(f_{t, u}\right)$ in function of the parameters previously defined.

The resulting tensile strengths can be seen in Table 4 and Figure 10. An initial increase in tensile strength values is followed by a decrease for high substitution percentages. For a $50 \%$ substitution, an increase in resistance of $9.5 \mathrm{MPa}$ is achieved, which represents an increase of $9 \%$, whereas for a $100 \%$ substitution, there is a loss of $20 \%$. For a substitution of $70 \%$, there is hardly any variation with respect to the control UHPFRC. As the error bars show, a high variability of the experimental results obtained for each substitution percentage is clear. This variation may be due to the random distribution of the fibres in the UHPFRC.

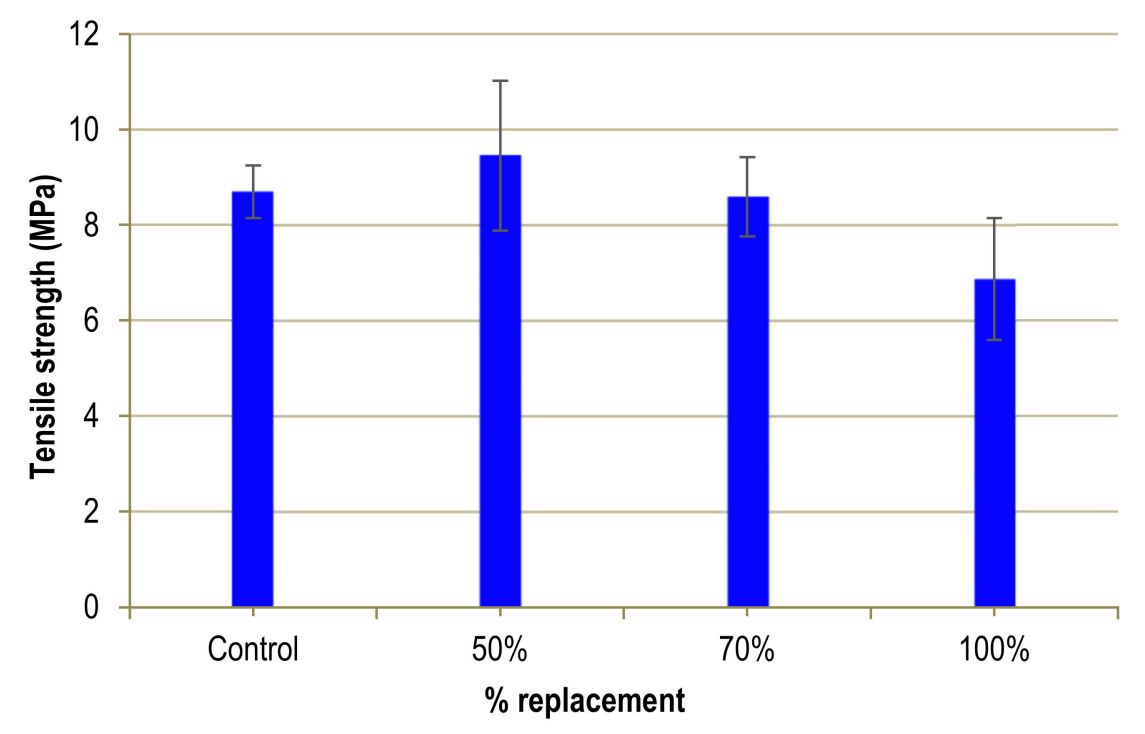

Figure 10. Tensile strength of UHPFRC.

The tensile strength results are similar to those of flexural strength, with an improvement for low substitution percentages followed by a drop that reaches $20 \%$ for a $100 \%$ substitution. The possible explanation, as in flexural strength, is the inferior quality of the mine sand used. The result obtained 
is similar to that of Taha [32] when analysing the influence of substituting glass waste for sand in the UHPC without fibres, although pointing out that the absence of fibres is an important factor. This author observes very little variation for $50 \%$ substitution, while for $100 \%$, he reports a loss of tensile strength of $5 \%$. As mentioned in the previous section, Taha considers that this loss may be due to small cracks present in the particles of the glass waste.

\section{Conclusions}

In this research, two main findings have been identified, which could explain the results obtained in the laboratory tests. The first is that the grading curve of the mixtures shows a more continuous distribution of the particle size, which improves packaging and reduce water requirements. The second is that the quality of mining sand is slightly inferior given that it contains $10 \% \mathrm{CaO}$ as opposed to the natural sand it substitutes, which is almost $100 \% \mathrm{SiO}_{2}$. The overall consequence is that the improvement in packaging leads to an improvement in mechanical properties up approximately $70 \%$ of replacement, at which point the lower quality of waste mining sand counteracts the advantages of the better packaging.

In view of the results obtained in this work, it can be established that waste sand from fluorite mines (WMS) is a viable alternative as a partial substitution of silica sand in the manufacturing of Ultra High Performance Fibre Reinforced Concrete (UHPFRC). The most relevant conclusions are the following:

The incorporation of WMS improves the consistency of fresh UHPFRC due, probably, to its smaller particle size generating a lubrication effect of the mixture.

The density of UHPFRC with WMS is very similar to the density of the control concrete. The variations are very small, less than $2.5 \%$, for any percentage of substitution.

The improved consistency of fresh UHPFRC with WMS and its smaller particle size favours the coMPactness of the concrete and causes an increase in compressive strength around $11 \%$ for all substitution percentages.

There is a slight decrease in the modulus of elasticity, which does not reach $6 \%$ for a $100 \%$ substitution with WMS, so the influence of using this type of waste on the modulus of elasticity of UHPFRC is negligible.

The results of flexural strength and tensile strength obtained show high variability for each substitution percentage. This may be a consequence of an inefficient distribution of the short steel fibres present in these concretes. However, the variations are small up to $70 \%$ substitution. Only for substitutions of $100 \%$ is there a significant loss in flexural strength and tensile strength, which reach values of $17 \%$ and $20 \%$, respectively.

It can be held that the use of up to $70 \%$ of waste mine sand as a substitute for natural sand is a totally feasible option for manufacturing UHPFRC, given that it has a minimal effect on any of its mechanical properties. However, for a ratio of $100 \%$ of substitution there is a drop of over $15 \%$ in tensile and flexural strengths, making the use of this substitution percentage inadvisable.

Author Contributions: Conceptualization, M.S.L and F.L.G.; methodology, F.S. and I.L.B.; validation, F.S. and F.L.G. investigation, J.S.G. and C.L-C.P.; resources, J.S.G. and I.L.B. writing-original draft preparation, I.L.B and J.S.G.; writing-review and editing, M.S.L. and J.S.G.; visualization, C.L.-C.P. and M.S.L.; supervision, C.L.-C.P. and F.L.G.; project administration, F.L.G.; funding acquisition, F.L.G. and J.S.G. All authors have read and agreed to the published version of the manuscript.

Funding: This research was funded by the Spanish Ministry of Economy and Competitiveness through the research project grant number BIA2016-78460-C3-2-R.

Acknowledgments: The authors also want to thank the support to carry out this study to ArcelorMittal, Elkem, Basf, Sika AG, Grupo Minersa, and the Ministry of Economy and Competitiveness of the Government of Spain. The support of CERIS research centre and Instituto Superior Técnico is also acknowledged.

Conflicts of Interest: The authors declare no conflict of interest. 


\section{References}

1. Richard, P.; Cheyrezy, M. Composition of reactive powder concretes. Cem. Concr. Res. 1995, 25, 1501-1511. [CrossRef]

2. Bétons Fibrés à Ultra-Hautes Performances, Recommandations Provisoires, Ultra High Performance Fibre-Reinforced Concretes, Interim Recommendations, SETRA-AFGC, Groupe de travail BFUP: Paris, France, January 2002. (in French and English). Available online: http://dtrf.setra.fr/pdf/pj/Dtrf/0002/Dtrf-0002989/ DT2989.pdf?openerPage=resultats\&qid=sdx_q0 (accessed on 27 May 2020).

3. Schmidt, C.; Glotzbach, S.; Fröhlich, S.; Piotrowski, S. Sustainable building with UHPC—Coordinated research program in Germany. In Proceedings of the Hipermat 2012 3rd International Symposium on UHPC and Nanotechnology for High Performance Construction Materials, Kassel, Germany, 7-9 March 2012.

4. Abbas, S.; Soliman, A.M.; Nehdi, M.L. Exploring mechanical and durability properties of ultra-high performance concrete incorporating various steel fiber lengths and dosages. Constr. Build. Mater. 2015, 75, 429-441. [CrossRef]

5. Fernandez Cánovas, M. Hormigón; Colegio de Ingenieros de Caminos, Canales y Puertos: Madrid, Spain, 2013.

6. Ambily, P.; Umarani, C.; Ravisankar, K.; Prem, P.R.; Bharatkumar, B.; Iyer, N.R. Studies on ultra high performance concrete incorporating copper slag as fine aggregate. Constr. Build. Mater. 2015, 77, $233-240$. [CrossRef]

7. Zhu, Z.; Li, B.; Zhou, M. The Influences of Iron Ore Tailings as Fine Aggregate on the Strength of Ultra-High Performance Concrete. Adv. Mater. Sci. Eng. 2015, 2015, 412878. [CrossRef]

8. Zhao, S.; Fan, J.; Sun, W. Utilization of iron ore tailings as fine aggregate in ultra-high performance concrete. Constr. Build. Mater. 2014, 50,540-548. [CrossRef]

9. Yang, S.; Millard, S.; Soutsos, M.; Barnett, S.; Le, T. Influence of aggregate and curing regime on the mechanical properties of ultra-high performance fibre reinforced concrete (UHPFRC). Constr. Build. Mater. 2009, 23, 2291-2298. [CrossRef]

10. Soliman, N.; Tagnit-Hamou, A. Using glass sand as an alternative for quartz sand in UHPC. Constr. Build. Mater. 2017, 145, 243-252. [CrossRef]

11. Zegardlo, B.; Szelag, M.; Ogrodnik, P. Ultra-high strength concrete made with recycled aggregate from sanitary ceramic wastes-The method of production and the interfacial transition zone. Constr. Build. Mater. 2016, 122, 736-742. [CrossRef]

12. Singh, S.; Nagar, R.; Agrawal, V.; Rana, A.; Tiwari, A. Sustainable utilization of granite cutting waste in high strength concrete. J. Clean. Prod. 2016, 116, 223-235. [CrossRef]

13. Boadella, I.L.; Gayarre, F.L.; González, J.M.S.; Gómez-Soberón, J.M.; Pérez, C.L.-C.; Serrano-Lopez, M.A.; De Brito, J. The Influence of Granite Cutting Waste on The Properties of Ultra-High Performance Concrete. Materials 2019, 12, 634. [CrossRef] [PubMed]

14. Kala, D. Effect of granite Powder on Strength Properties of Concret. Int. J. Eng. Sci. 2013, 2, 36-50.

15. Estadísticas Sobre Residuos-Statistics Explained. 2018. Available online: http://ec.europa.eu/eurostat/ statistics-explained/index.php?title=Waste_statistics/es (accessed on 27 May 2020).

16. Estadísticas Sobre la Recogida y Tratamiento de Residuos. Encuesta Sobre Generación de Residuos en la Industria. 2014. Available online: http://www.ine.es/prensa/np1004.pdf (accessed on 27 May 2020).

17. Yu, R.; Spiesz, P.; Brouwers, H. Mix design and properties assessment of Ultra-High Performance Fibre Reinforced Concrete (UHPFRC). Cem. Concr. Res. 2014, 56, 29-39. [CrossRef]

18. EN 12390-1. Testing Hardened Concrete, Part 1: Shape, Dimensions and other Requirements for Specimens and Moulds; AENOR: Madrid, Spain, 2013. Available online: https://www.une.org/ (accessed on 27 May 2020).

19. UNE-EN 12390-2.Testing Hardened Concrete, Part 2: Making and Curing Specimens for Strength Test; AENOR: Madrid, Spain, 2009. Available online: https://www.une.org/ (accessed on 27 May 2020).

20. NF P 18-470. Bétons-Bétons Fibrés à Ultra Hautes Performances-Spécification, Performance, Production et Conformité, AFNOR: France. 2016. Available online: https://m.boutique.afnor.org/ (accessed on 27 May 2020).

21. EN 12390-7. Testing Hardened Concrete, Part 7: Density of Hardened Concrete; AENOR: Madrid, Spain, 2009; Available online: https://www.une.org/ (accessed on 27 May 2020).

22. EN 12390-13. Testing Hardened Concrete, Part 13: Determination of Secant Modulus of Elasticity in Compression; AENOR: Madrid, Spain, 2014; Available online: https://www.une.org/ (accessed on 27 May 2020). 
23. EN 12390-3. Testing Hardened Concrete, Part 3: Compressive Strength of Test Specimens; AENOR: Madrid, Spain, 2009; Available online: https://www.une.org/ (accessed on 27 May 2020).

24. Vogt, C. Ultrafine Particles in Concrete: Influence of Ultrafine Particles on Concrete Properties and Application to Concrete Mix Design. Ph.D. Thesis, School of Architecture and the Built Environment Division of Concrete Structures, Stockholm, Sweden, 2010.

25. Pyo, S.; Tafesse, M.; Kim, B.-J.; Kim, H.-K. Effects of quartz-based mine tailings on characteristics and leaching behavior of ultra-high performance concrete. Constr. Build. Mater. 2018, 166, 110-117. [CrossRef]

26. Kou, S.-C.; Xing, F. The Effect of Recycled Glass Powder and Reject Fly Ash on the Mechanical Properties of Fibre-Reinforced Ultrahigh Performance Concrete. Adv. Mater. Sci. Eng. 2012, 2012, 263243. [CrossRef]

27. Albarwary, I.H.M.; AlDoski, Z.N.S.; Askar, L.K. Effect of Aggregate Maximum Size upon Compressive Strength of Concrete. J. Univ. Duhok 2017, 20, 790-797. [CrossRef]

28. Raheem, A.H.A.; Mahdy, M.; Mashaly, A.A. Mechanical and fracture mechanics properties of ultra-high-performance concrete. Constr. Build. Mater. 2019, 213, 561-566. [CrossRef]

29. Ibrahim, M.A.; Farhat, M.; Issa, M.A.; Hasse, J.A. Effect of Material Constituents on Mechanical and Fracture Mechanics Properties of Ultra-High-Performance Concrete. ACI Mater. J. 2017, 114, 453-465. [CrossRef]

30. Alsalman, A.; Dang, C.; Prinz, G.S.; Hale, W.M. Evaluation of modulus of elasticity of ultra-high performance concrete. Constr. Build. Mater. 2017, 153, 918-928. [CrossRef]

31. Gonzalez-Corominas, A.; Etxeberria, M. Properties of high performance concrete made with recycled fine ceramic and coarse mixed aggregates. Constr. Build. Mater. 2014, 68, 618-626. [CrossRef]

32. Taha, B.; Nounu, G. Properties of concrete contains mixed colour waste recycled glass as sand and cement replacement. Constr. Build. Mater. 2008, 22, 713-720. [CrossRef]

33. Martínez, J.A.L. Characterisation of the Tensile Behaviour of Uhpfrc by Means of Four-Point Bending Tests. Ph.D. Thesis, Universitat Politecnica de Valencia, Valencia, Spain, 2017.

(C) 2020 by the authors. Licensee MDPI, Basel, Switzerland. This article is an open access article distributed under the terms and conditions of the Creative Commons Attribution (CC BY) license (http://creativecommons.org/licenses/by/4.0/). 